Vol.01/ No. 02

Pages: 58-71

https://www.irojournals.com/iroeea

DOI: https://doi.org/10.36548/jeea.2019.2.001

\title{
Extract Maximum Power from PV System Employing MPPT with FLC Controller
}

\author{
A. Chandramouli, \\ Research scholar, Sathyabama Institute of Science and Technology. \\ Department of Electrical and Electronics Engineering, \\ S R Engineering College, Warangal, \\ India. \\ Dr. V. Sivachidambaranathan, \\ Department of Electrical and Electronics Engineering, \\ Sathyabama Institute of Science and Technology, \\ Chennai, India.
}

\begin{abstract}
Extract of maximum power from photo voltaic (PV) system employing with fuzzy logic controller (FLC) based MPPT technique is investigated in this article. Fuzzy is a expert supervisory control algorithm system, provides satisfied acceptable results from PV. Maximum/lower power point tracking (MPPT/LPPT) approaches are adopted to get maximum output power from the PV irrespective of variation in its input source (Solar irradiation and temperature). The performance results have been investigated in MATLAB/Simlink package for different conditions. From the simulation results it is evident that proposed fuzzy control algorithm works well compared to the other traditional MPPT techniques.
\end{abstract}

Key Words - Photo voltaic system, MPPT techniques, FLC controller

\section{INTRODUCTION:}

Since a decade power generation through renewable energy sources are rapidly growing because of its numerous features such as free from green house problems, environmental friendly, and no acid rain and doesn't create any problem to ozone layer. Various types of RES are available like solar, wind, geothermal and wind etc, in these solar is more dominant to adopt distribution power generation because it doesn't contains rotating parts to generate power [1-4].

Power generation is available in different source like hydro, thermal, geo thermal, nuclear etc.., these power generations inserting various gases in the air and polluting environment much. This problem mainly overcomes by solar power generation. A PV cell converts light energy into electricity without having mechanical (rotating) parts. Because of absence of rotating parts solar power generation has less loss [5-10].

The field of solar Photovoltaic (PV) has been growing very fast and it is expected to grow further, possibly with higher rate. Worldwide, the production of PV modules is increasing. During 2014, the worldwide production of PV modules was about 40,000 MW. As the cost of PV modules going down, the electricity produced using solar 
Journal of Electrical Engineering and Automation (EEA) (2019)

Vol.01/ No. 02

Pages: 58-71

https://www.irojournals.com/iroeea

DOI: https://doi.org/10.36548/jeea.2019.2.001

PV is becoming cheaper and many scenarios it is becoming economically viable alternative supply. Worldwide many governments have been announcing policies to support growth of solar PV technologies.

The main focus of this article is demand for the electrical energy increasing every day, and the availability of fossil fuel sources declining day by day, this made me to think about alternative energy source solar energy by using MPPT and FLC controller. A lot of research is being going on this area, but still the effective utilization of solar energy is not happening. This thing motivates me to work on extract maximum power from the solar cell, and to connect the solar cell effectively to the grid, and to contribute my way of thoughts towards the power quality improvement of the system, when a solar cell is connected to the grid.

\section{PHOTOVOLTAIC SYSTEMS}

SECS systems are majorly divided and discussed into two ways [] i.e. Stand-alone PV frameworks and grid-integrated PV frameworks, its sub categories are described in below figure. The main difference between this systems are, in stand-alone systems production of solar output power is equal to the load demand. Where grid connected PV systems are involves direct power generations at domestic or industrial. The classification of PV systems are shown in figure. 1

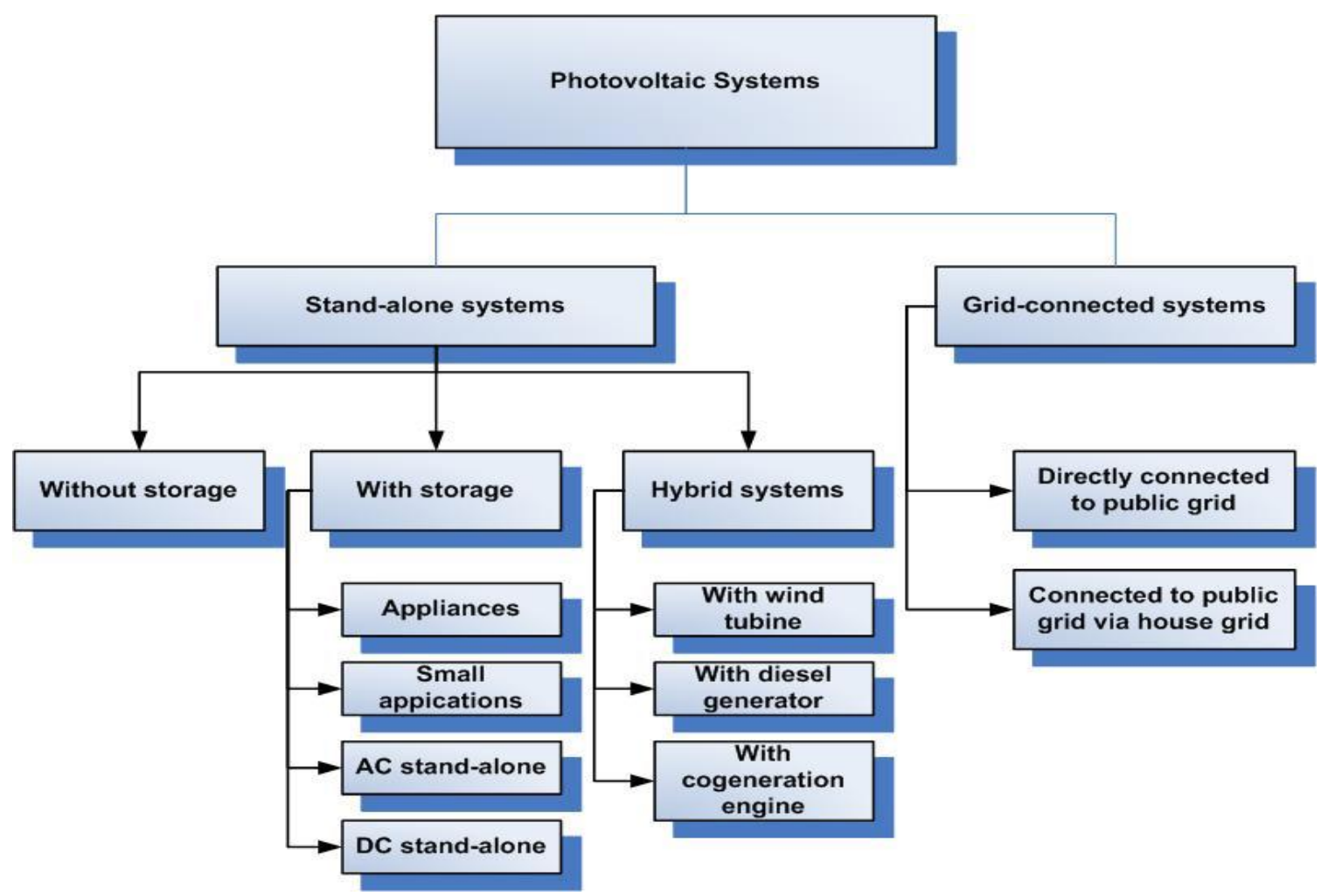


Figure 1 Classification of PV systems

\section{A. PV CELL}

The general PV cell is representing below fig.2, generally the power generating From PV cell is depending upon the solar irradiation based on this irradiation only we can generate the power Fig.2 demonstrate the operation of a PV cell the p-n homo junction cell is utilized [16-19].

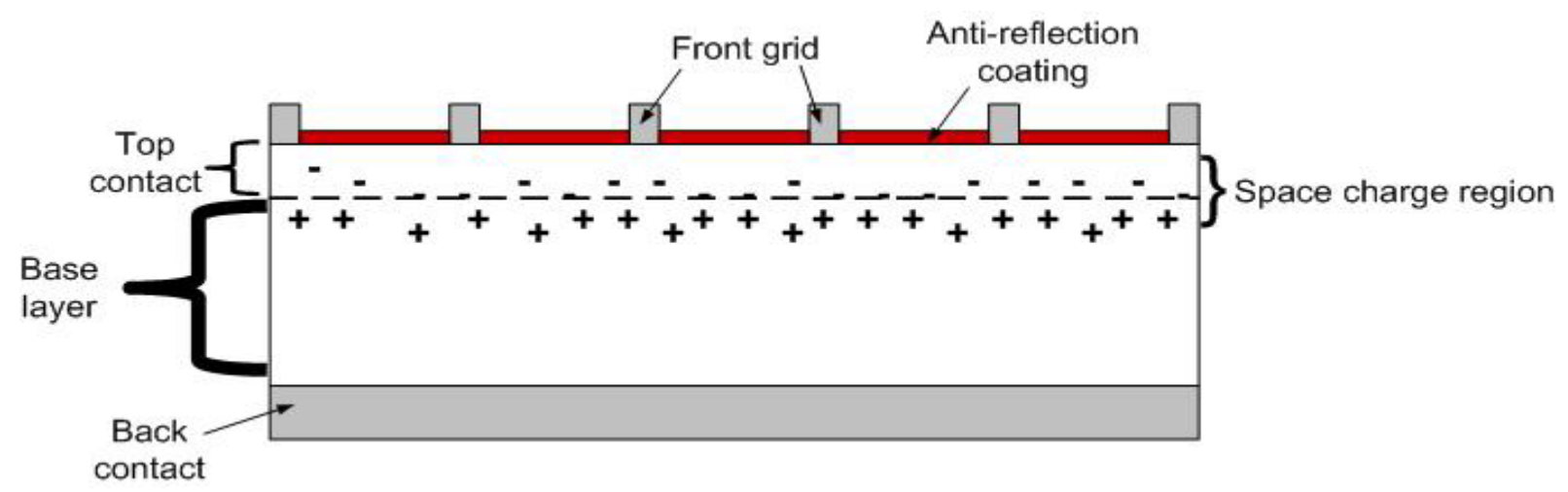

Figure 2 Structure of a PV cell

During night period PV cell is behaves as similar to diode. Current through diode is expressed as

$$
\mathrm{i}=I_{S}\left(e^{\frac{q V}{\beta k T}}-1\right)
$$

To produce more electricity more countable no.of PV cells connected in series or parallel combinations. The typical layout of 36 or 72 PV cell connection is shown in fig.3.

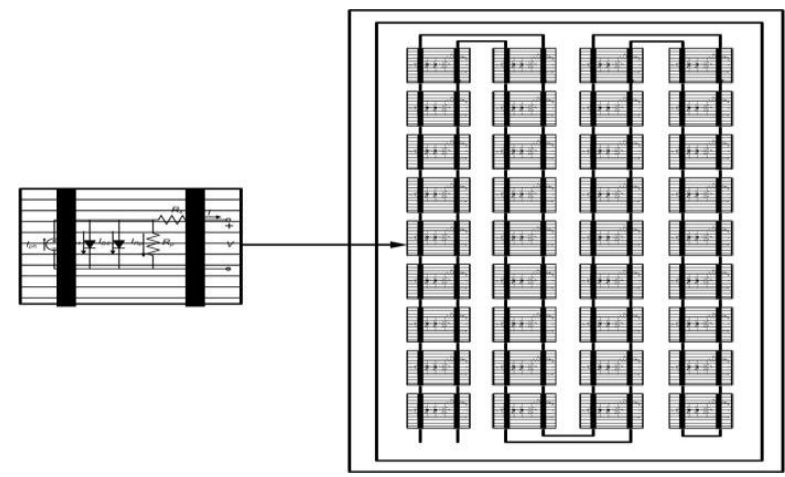

Figure 3 Structure of a PV module 
Vol.01/ No. 02

Pages: 58-71

https://www.irojournals.com/iroeea

DOI: https://doi.org/10.36548/jeea.2019.2.001

\section{B. PV ARRAY:}

PV array is defined as interconnection of ' $n$ ' no. of PV module in a single plane. This mountain highly required to produce sufficient electrical power form sun light. The range of PV array rating is hundred watts or fractional kilowatts. The schematic or typical layout of PV array is represented in fig.4, where 4 PV modules are connected in series to reach power demand. Voltage and current production when ' $\mathrm{n}$ ' no.of PV modules are connected in series mathematically it is given as

$$
\begin{aligned}
& V_{\text {series }}=\sum_{j=1}^{n} V_{j}=V_{1}+V_{2}+\ldots \ldots \ldots+V_{n} \\
& V_{\text {seriesoc }}=\sum_{j=1}^{n} V_{j}=V_{o c 1}+V_{o c 2}+\ldots \ldots \ldots .+V_{o c n} \text { for } \mathrm{I}=0 \\
& I_{\text {parallel }}=\sum_{j=1}^{n} I_{j}=I_{1}+I_{2}+\ldots \ldots \ldots+I_{n} \\
& V_{\text {parallel }}=V_{1}=V_{2}=\ldots \ldots . .=V_{n}
\end{aligned}
$$

Generally PV array's have bypass diodes to reduce over voltages in the SECS system. Because of presence of bypass diodes overall system cost is increase.

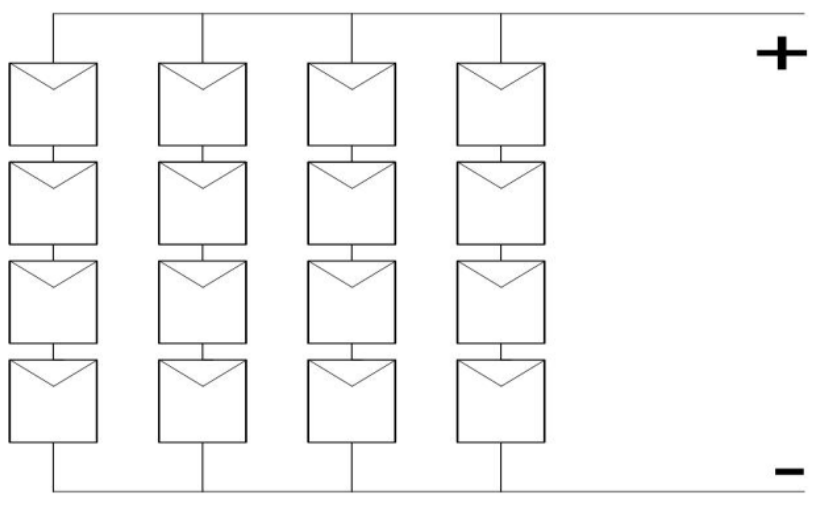

Figure 4 Typical layout of PV array

\section{PV-HYBRID SYSTEMS}

The PV hybrid systems with loads are including power electronic switching components are shown below figure.5. 
Vol.01/ No. 02

Pages: 58-71

https://www.irojournals.com/iroeea

DOI: https://doi.org/10.36548/jeea.2019.2.001

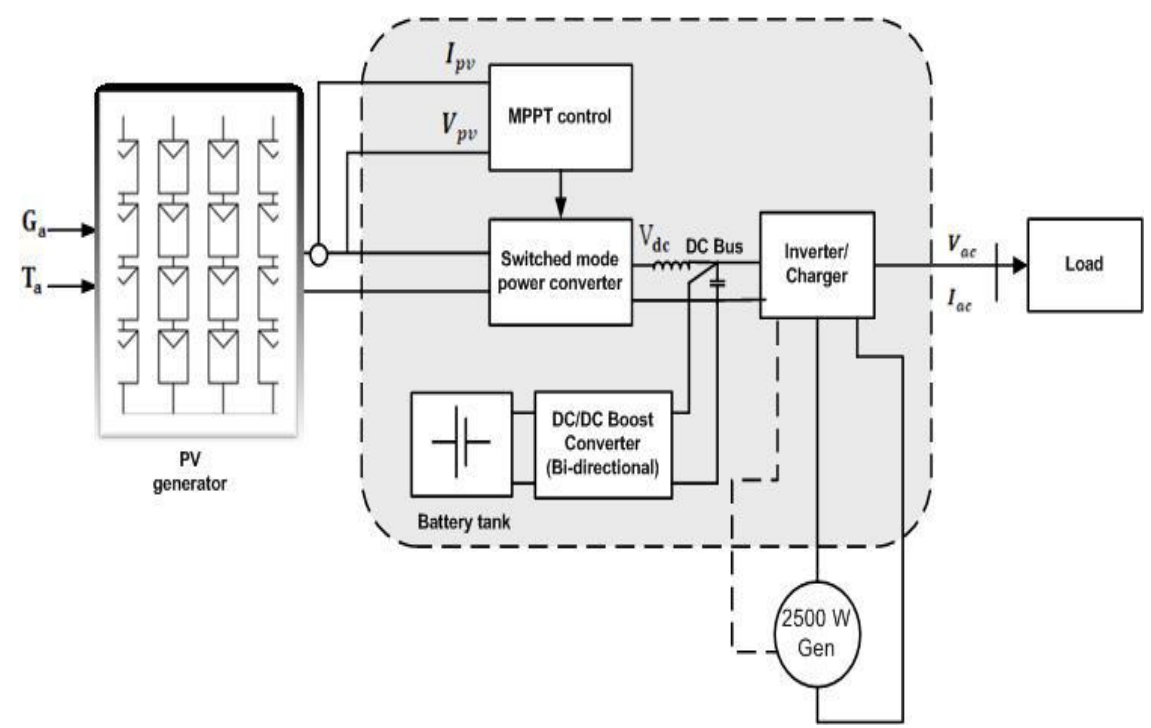

Figure 5 Hybrid stand-alone PV frameworks

\section{PV CELL MODEL}

Ideal PV cell is characterized with a current source in parallel with a diode, and series resistance and a shunt resistance. Where series and shunt resistances are controls the power production [18-19].

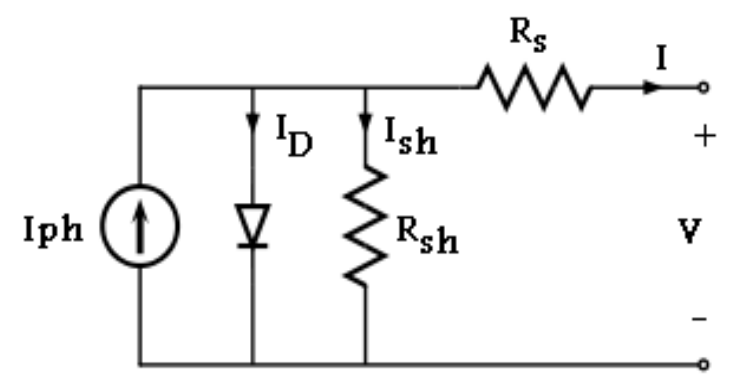

Figure 6 schematic diagram of PV Cell

The load current (I), mathematically expressed as

$\mathrm{I}=I_{p h}-I_{s}\left(\exp q \frac{\left(v+R_{s} I\right)}{N K T}\right)-1-\left(\frac{v+R_{s} I}{R_{s h}}\right)$

Where

Iph $=$ PV current 
Vol.01/ No. 02

Pages: 58-71

https://www.irojournals.com/iroeea

DOI: https://doi.org/10.36548/jeea.2019.2.001

Rse and $R s h$ are the series and shunt resistors of the cell correspondingly.

$I s=$ Diode reverse saturation current

$q=$ electron charge

$V=$ voltage across diode terminals

$K=$ Boltzmann's constant

$T=$ temperature across junction

$N=$ Diode ideality factor.

\section{DC-DC CONVERTERS IN PHOTOVOLTAIC SYSTEMS:}

One traditional technique for performing power transfer from a definite dc source to a definite dc load is by utilizing switched-mode dc-dc converters. Here, the power transfer is on the basis of switching action, where the energy is occasionally stored into magnetic fields and subsequently released to load using controllable switches. On employing switched-mode conversion, there becomes greater possibility in obtaining higher conversion efficiency, as the required quantity of power demanded by the system load is consumed from the corresponding system source. If possible, this shall result in a lossless conversion. But, numerous loss mechanisms decrease the efficiency, and characteristically switched-mode converters attain conversion efficiencies around 80 to 98 percentage, depending on the conversion type and power level. An alternate technique for obtaining dc-dc conversion is to exploit linear regulators. Linear regulators will not contain switching elements, but the operating principle is on the basis of dissipating additional power that is not necessary by the load into heat. Alternatively, linear regulator operates as a controllable resistor either in series with voltage source or in parallel with current source.

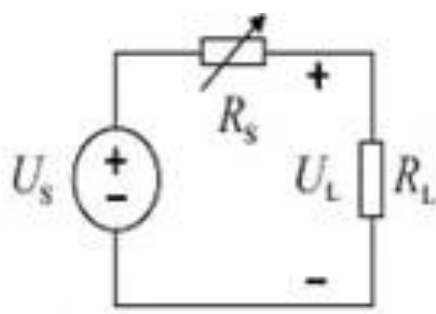

(a) Series regulator

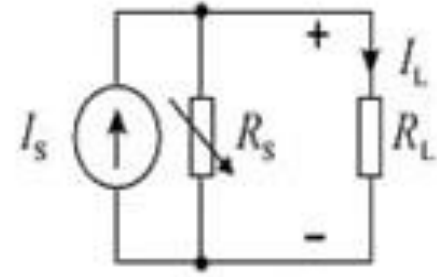

(b) Shunt regulator

Figure 7 Linear regulator types for boost converters for a photovoltaic system

Because of the lack of switching actions, linear regulator is only able to deliver power transfer from high to low voltage levels or from high to low current levels. The characteristic advantage of linear regulator is its simplicity in designing, because of operational principles and lesser quantity of electrical noise in comparison with 
switched-mode converters. As a result, linear regulator is typically employed in applications that require lownoise power supply, like high fidelity audio systems. Figure 4 shows the linear regulator categories that are employable in boost converter for photovoltaic systems.

The last phase towards power conversion chain is grid- connected inverter that allows power transfer from dc sources into ac loads, functioning over analogous switching actions with that of dc-dc converters. For feeding distortion-less current to ac grid as uttered by the grid regulation codes, the traditional VSI-type 2 inverter necessitates that the input voltages to be greater than the peak value of the grid voltages. Considering one inverter that is connected with one $230-\mathrm{V}$ single-phase grid, then the needed input voltage is characteristically $350-\mathrm{V}$, however for three phase inverters connected with $400-\mathrm{V}$ grids, the input voltage is to be $700-\mathrm{V}$. This limitation towards input voltage levels that is fixed by the inverters shall be rectified by either connecting adequate quantity of PV units into a string or by employing dc-dc converter. These kinds of organizations are frequently employed in high-power PV power plants because of reduced quantity of power conversion stages, thereby decreasing power loss created by multi-stage conversions. Nevertheless, more quantity of PV modules is necessary, resulting in larger difference over MPP voltages caused by environmental conditions. The design of inverter thus becomes highly complex, because power stages have to be calculated to tolerate larger variations in input voltage while upholding higher operational efficiency.

\section{PROPOSED SYSTEM}

For any PV system, the output power can be increased by tracking the MPP (Maximum Power Point) of the PV module by using a controller connected to a dc- dc converter (usually boost converter). However, the MPP changes with insolation level and temperature due to the nonlinear characteristic of PV modules. Each type of PV module has its own specific characteristic. In general, there is a single point on the V-I or V-P curve, called the Maximum Power Point (MPP), at which the entire PV system operates with maximum efficiency and produces its maximum output power. This point can be located with the help of MPPT.

The circuit configuration of PV system with fuzzy MPPT controller is shown in figure 8 .

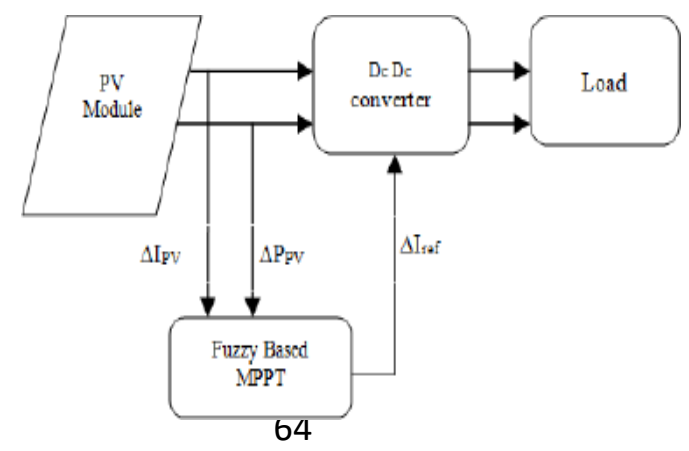


Figure 8 Block diagram of proposed system

\section{PROPOSED FUZZY LOGIC CONTROLLER:}

The FLC controller uses the fuzzy logics to make the decisions and to control the output of the controller. The main components in fuzzy logic based MPPT controller are fuzzification, rule-base, and inference and defuzzification as shown in figure 9 .

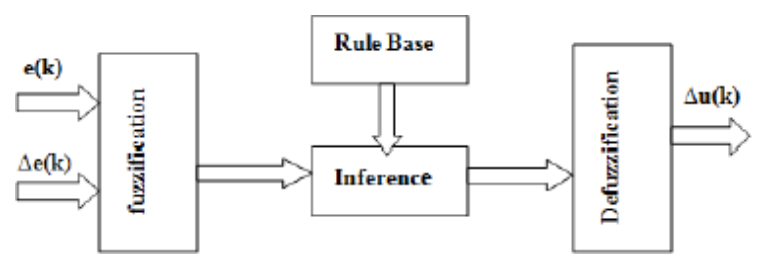

Figure 9 Fuzzy logic block diagram

The Membership functions and rule base are designed with the help of Fuzzy Logic Tool Box in MATLAB. The membership function graphical view for error is represented by Fig.11. Change of error is

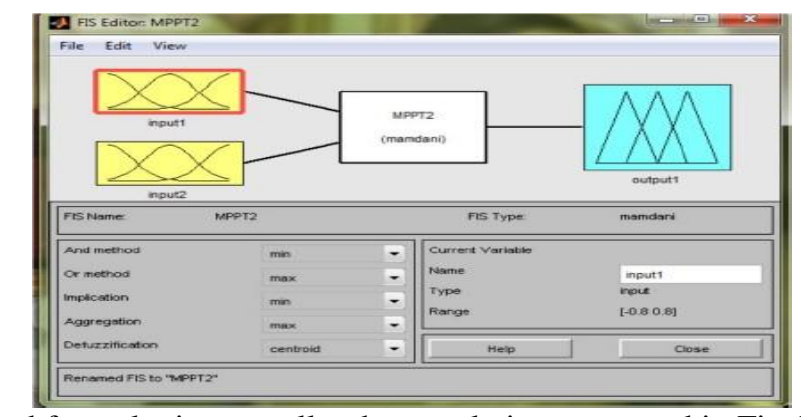

represented by Fig.12 and fuzzy logic controller duty cycle is represented in Fig.13.

Figure 10 Fuzzy logic Implementation in Simulation 
Vol.01/ No. 02

Pages: 58-71

https://www.irojournals.com/iroeea

DOI: https://doi.org/10.36548/jeea.2019.2.001
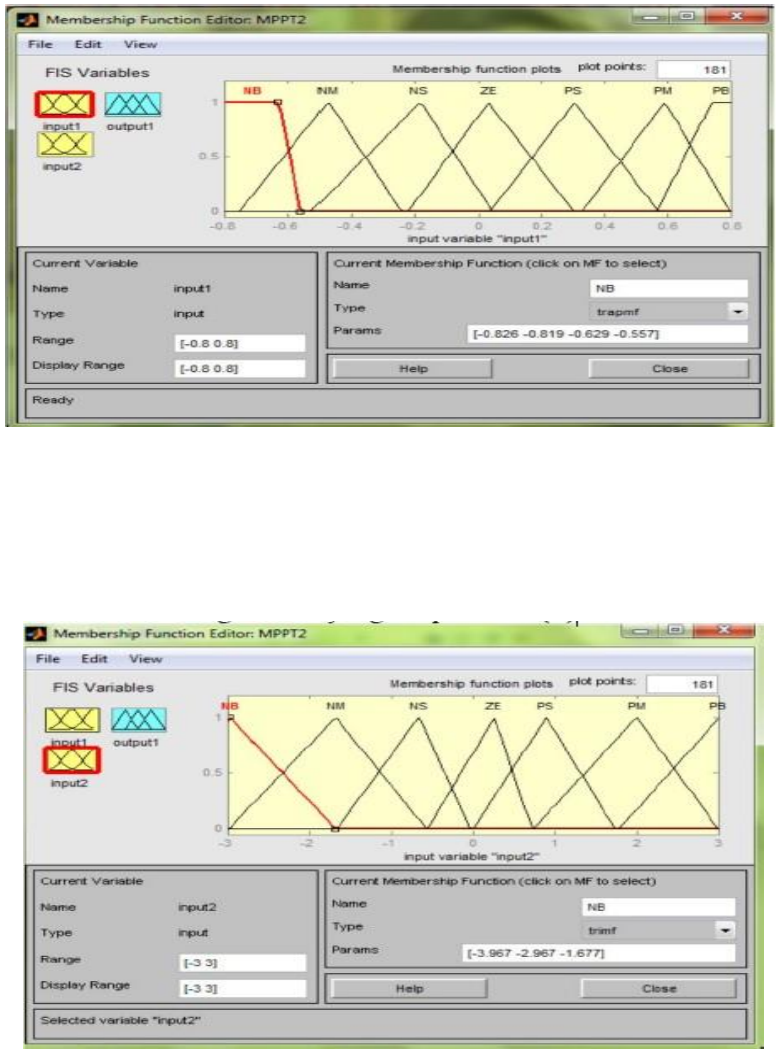

Figure 11 Fuzzy logic input Error (E)

Figure 12 Fuzzy logic input change of Error (CE)

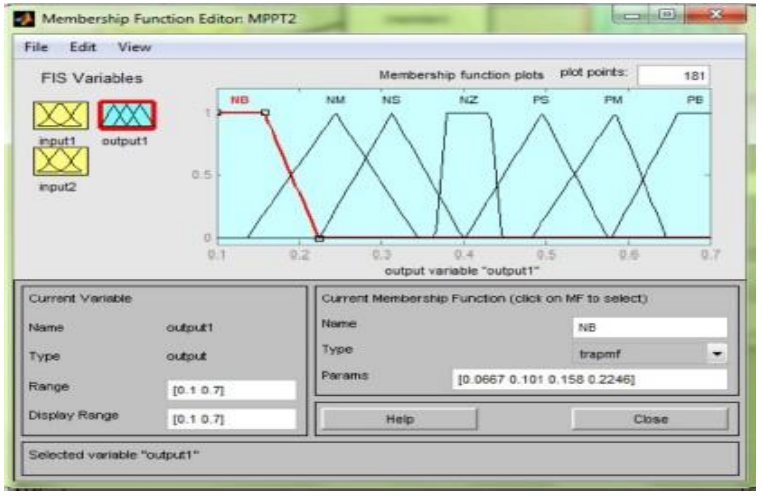

Figure 13 Fuzzy logic output (D)

Graphic view of the membership function for (a) error signal (b) change of error signal and (c) duty cycle. Different number of subsets has been used for rule settings of fuzzy logic MPPT. In this case, seven subsets based on forty- nine rules were used. The tuning of forty nine rules represents a better precision and dynamic response but it is time consuming. 
Journal of Electrical Engineering and Automation (EEA) (2019)

Vol.01/ No. 02

Pages: 58-71

https://www.irojournals.com/iroeea

DOI: https://doi.org/10.36548/jeea.2019.2.001

\section{SIMULATION RESULTS:}

The proposed FLC based MPPT technique model as shown in the figure 14.

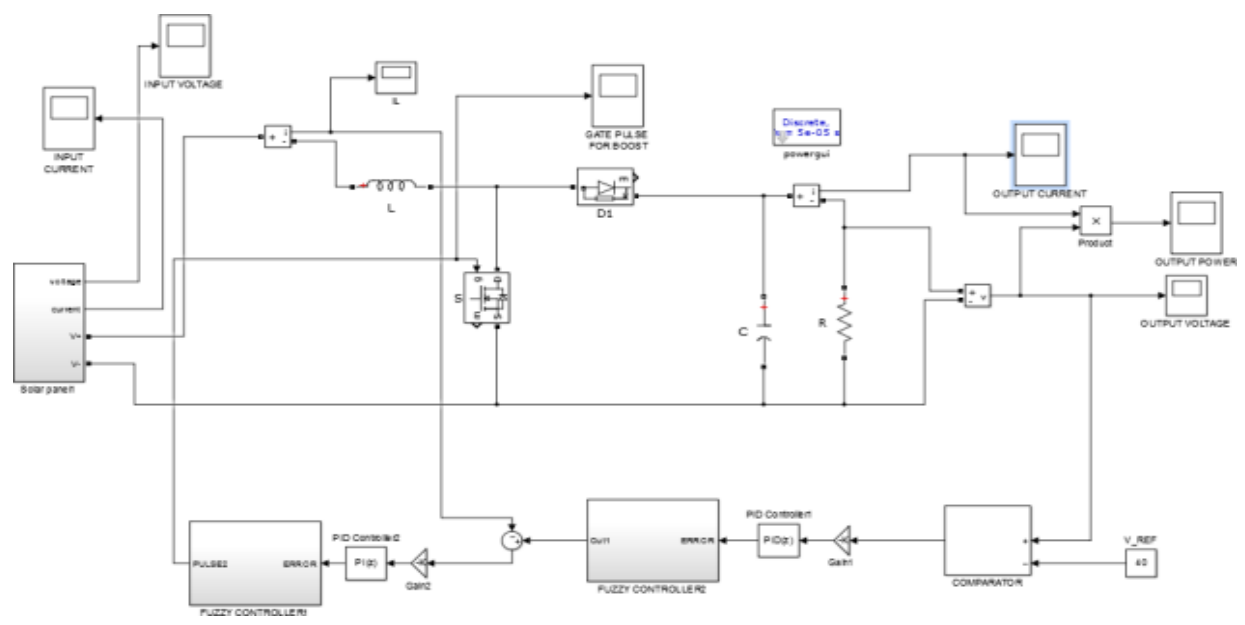

Figure 14 MATLAB configuration of proposed system

\section{CASE-1 PV INPUT VOLTAGE (14V):}

The simulation waveform of output voltage and current of PV, output voltage, output current and output power across load terminals are shown in figure 15 to 19 respectively as below.

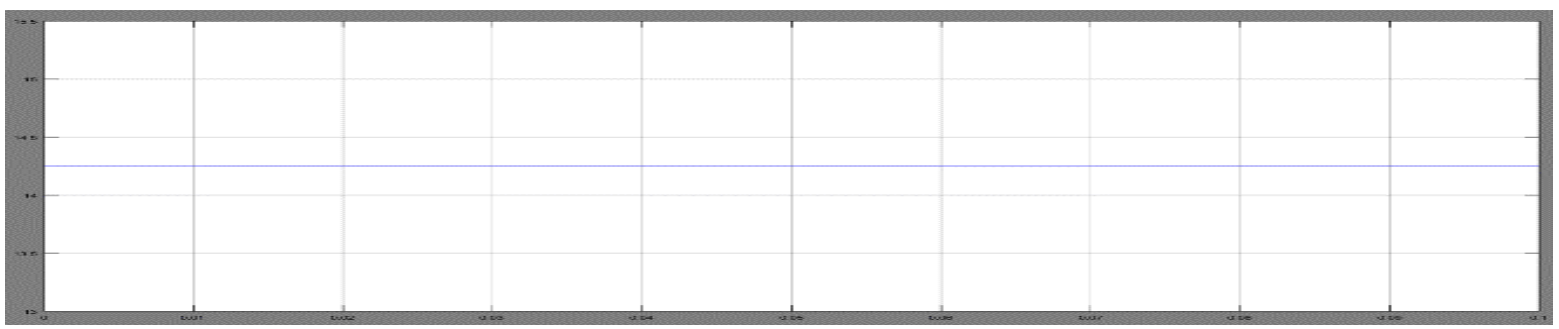

Figure $15 \mathrm{Vpv}(\mathrm{PV}$ Voltage)

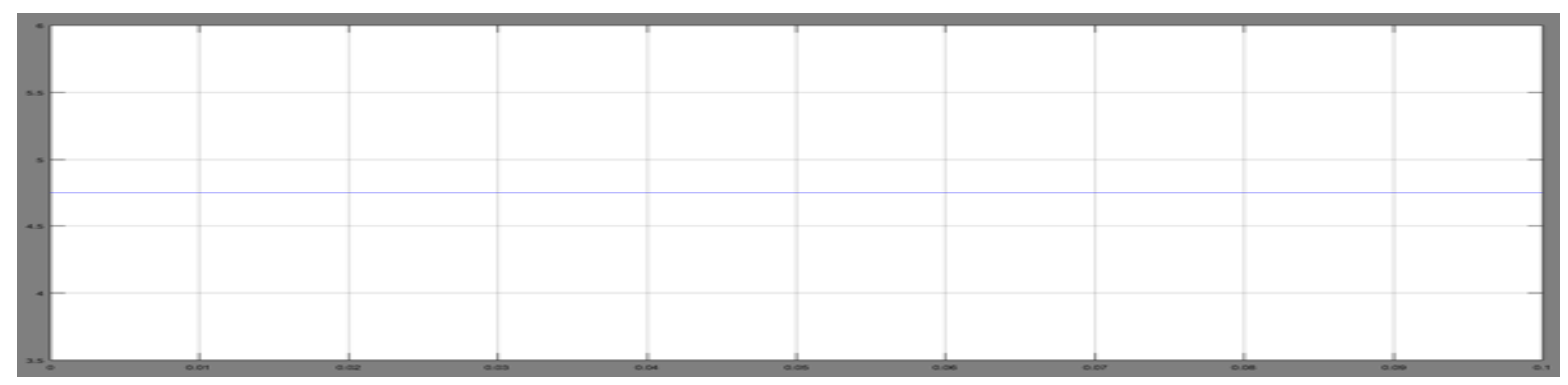

Figure 16 Ipv (PV Current) 
Journal of Electrical Engineering and Automation (EEA) (2019)

Vol.01/ No. 02

Pages: 58-71

https://www.irojournals.com/iroeea

DOI: https://doi.org/10.36548/jeea.2019.2.001

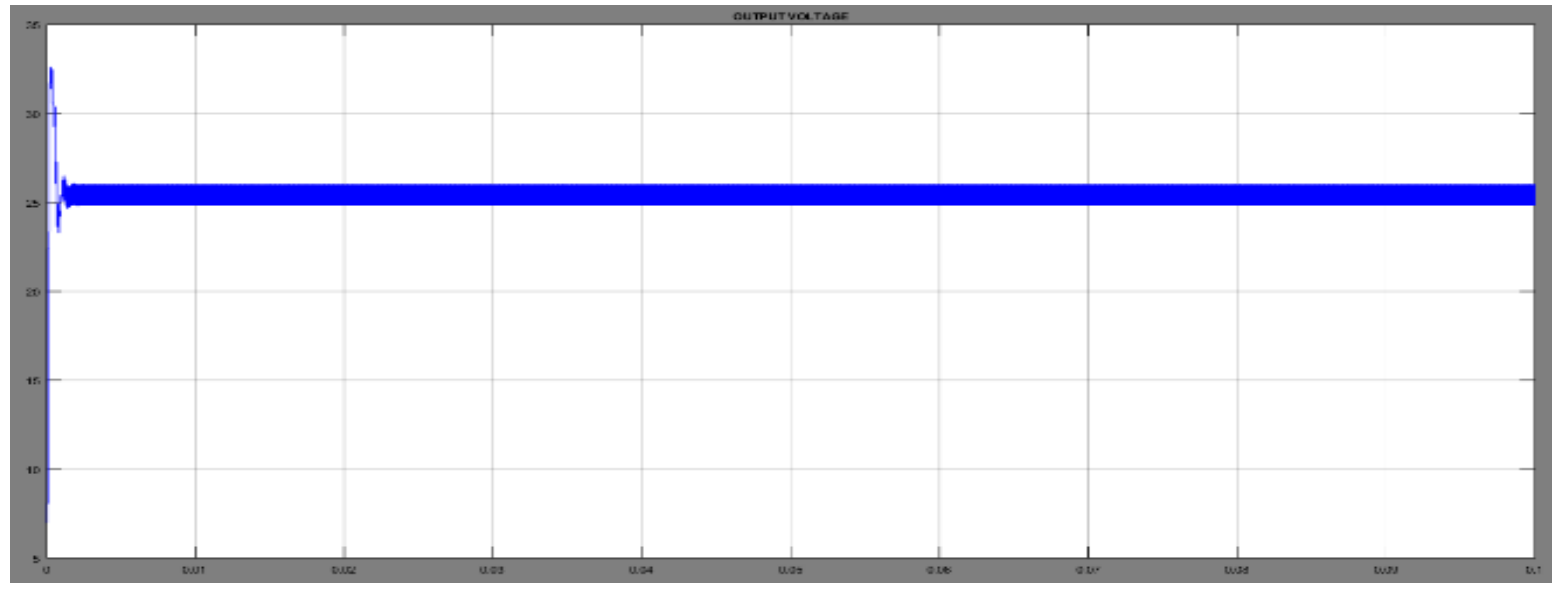

Figure 17 Output Voltage

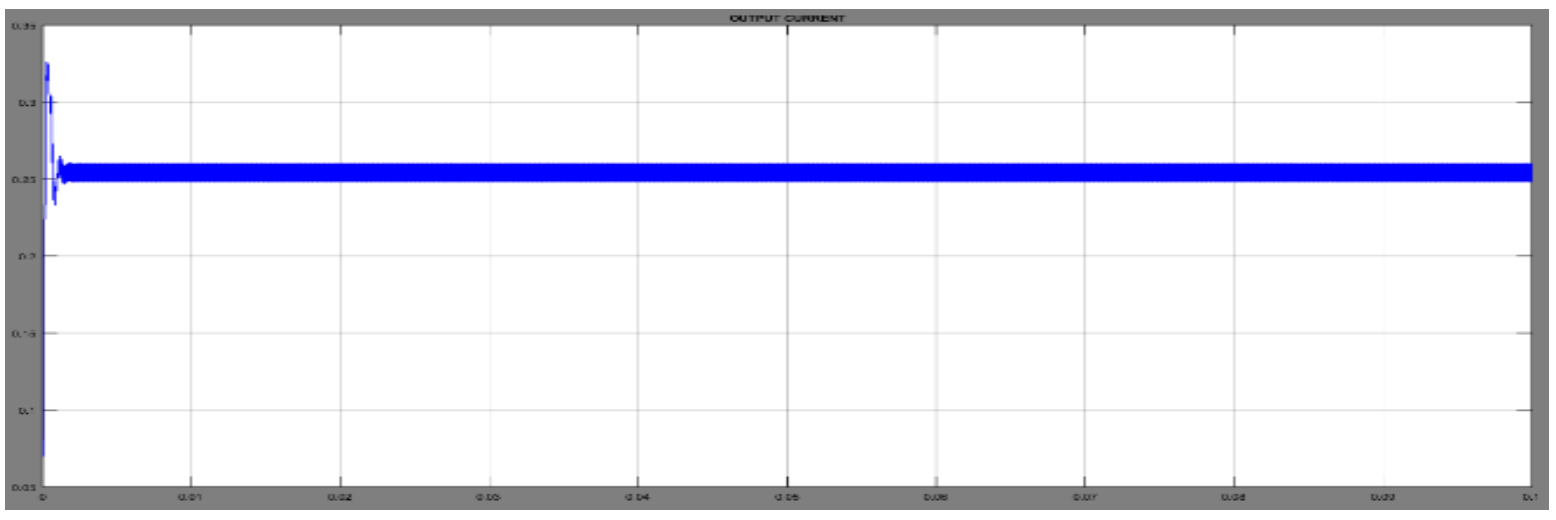

Figure 18 Output Current

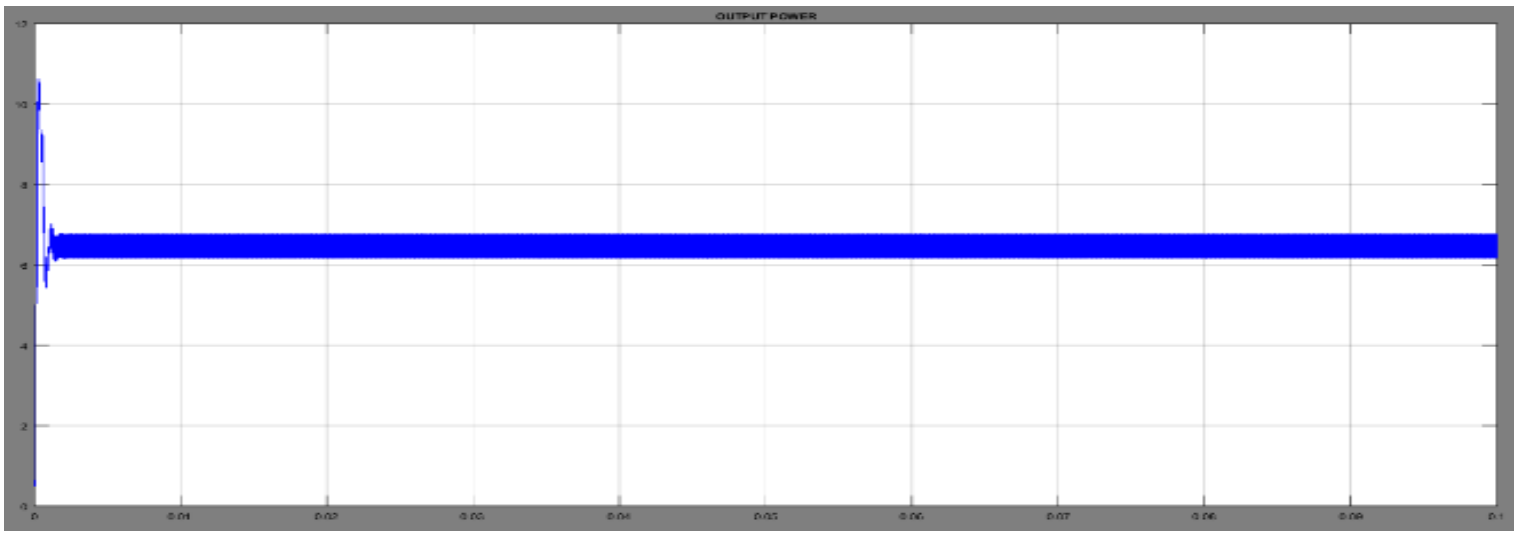

Figure 19 Output power 


\section{CONCLUSION}

Fuzzy is an intelligent control algorithm based system works faster than conventional MPPT approaches such as P\&O, IC and modified few MPPT approaches. In this, the MATLAB/Simulink model of FLC based MPPT technique presented with desired output voltages and output currents. From the simulation results it is well known that the proposed PV system becomes more efficient when a MPPT controller FLC is included added in the system. By selecting the number of membership functions, it has been proved that MPPT will follow the exact MPP point and thereby the overall efficiency of the photo voltaic system can be improved. In the future, the designed model can be implemented in hardware setup with digital controllers.

\section{REFERENCES}

[1] Kavitha.M and Sivachidambaranathan.V, (2016) "PV Based High Voltage Gain quadratic DC-DC converter integrated with coupled inductor”, IEEE International Conference on Computation of Power, Energy Information and Communication (ICCPEIC), ISBN 978-1-5090-0901-5, 20-21 April, 2016, pp 607-612.

[2] Preeti Pauline Mary and Sivachidambaranathan.V (2015), "Design of New Bi-Directional Three Phase Parallel Resonant High Frequency AC Link Converter”, International Journal of Applied Engineering Research (ISSN 0973-4562), Vol 10, Number 4, PP 8453-8468.

[3] M.Preeti Pauline Mary and V.Sivachidambaranathan (2015), "Enhancement of Active Power Filter Operational Performance using SRF Theory for Renewable Source", Indian Journal of Science and Technology (ISSN 0974-6846), Vol 8 (21), 71562, September 2015, pp 1-7.

[4] Kavitha.M and Sivachidambaranathan.V (2018), "Comparison of Different Control Techniques for Interleaved DC-DC Converter”, International Journal of Power Electronics and Drive System (IJPEDS) (ISSN 2088-8694) - Vol. 9, No. 2, June 2018, pp. 641 647.

[5] Sivachidambaranathan.V (2014), "Bi-Directional Series Parallel Resonant Converter for Power Factor Correction", International Journal of Applied Engineering Research (ISSN 0973-4562), Vol 9, Number 21, PP 10953-10961.

[6] Sivachidambaranathan.V\&S.S.Dash (2010), "Simulation of Half Bridge Series Resonant PFC DC to DC Converter”, IEEE International Conference on “Recent Advances in Space Technology Services \& 
Journal of Electrical Engineering and Automation (EEA) (2019)

Vol.01/ No. 02

Pages: 58-71

https://www.irojournals.com/iroeea

DOI: https://doi.org/10.36548/jeea.2019.2.001

Climate Change - 2010" (RSTS\&CC-2010), Sathyabama University in association with Indian Space Research Organisation (ISRO), Bangalore and IEEE, ISBN 978-1-4244-9184-1, November 13-15, IEEE Explore pp 146-148.

[7] Kavitha.M and Sivachidambaranathan.V (2015), "Transformer less inverter using Unipolar Sinusoidal Pulse Width Modulation Technique for Grid Connected Photovoltaic Power System", International Journal of Applied Engineering Research (ISSN 0973-4562), Vol 10, Number 2, PP 3089-3100.

[8] Kashif I, Zainal S, Hamed T. "Simple, fast and accurate two-diode model for photovoltaic modules". Sol Energ Mat Sol C 2011; 95: 586 - 594.

[9] Ma T, Yang H, Lu L. "Development of a model to simulate the performance characteristics of crystalline silicon photovoltaic modules/strings/arrays", Sol Energy 2014; 100: 31 - 41.

[10] R. Arulmurugan, "Photovoltaic powered transformer less hybrid converter with active filter for harmonic and reactive power compensation", ECTI Transactions on Electrical Engineering, Electronics, and Communications, Vol.16, No.2, PP.44-51, August 2018

[11] Kashif I, Zainal S and Syafaruddin, "A comprehensive MATLAB Simulink PV system simulator with partial shading capability based on two-diode model", Sol energy 2011; 85: 2217 - 2227.

[12] era D, Teodorescu R, Rodriguez P. "PV panel model based on datasheet values", In: IEEE 2007 International Symposium on Industrial Electronics; 4-7 June 2007; Vigo, Spain: IEEE. pp. $2392-2396$.

[13] Lo Brano V, Ciulla G. "An efficient analytical approach for obtaining a five parameters model of photovoltaic modules using only reference data", Applied Energy 2013; 111: 894-903.

[14] Chatterjee A, Keyhani A, Kapoor D. "Identification of Photovoltaic Source Models", IEEE T Energy Conver 2011; 26: 883 - 889.

[15] Arulmurugan, R\&Venkatesan, T, "Research and Experimental Implementation of a CV- FOINC Algorithm Using MPPT for PV Power System", Journal of Electrical Engineering and Technology, vol.10, no.1, pp. 30-40, 2015

[16] Lun SX, Du CJ, Guo TT, Wang S, Sang JS, Li JP. "A new explicit I-V model of a solar cell based on Taylor's series expansion", Sol Energy 2013; 94: 221 - 232.

[17] Soon JJ, KS Low. "Photovoltaic Model Identification Using Particle Swarm Optimization with Inverse Barrier Constraint", IEEE Trans. Power Electr 2012; 27: 3975 - 3983.

[18] Arulmurugan, R, "Comparative evaluation of new FLC controller based MPPT for a DC to DC buckboost zeta converter" WSEAS Transactions on power systems, vol.11, pp.27-34, 2016, E-ISSN: 2224$350 \mathrm{X}$

[19] Liu G, Nguang SK, Partridge A. "A general modeling method for I-V Conversion characteristics of geometrically and electrically configured photovoltaic arrays". Energy Convers Manage 2011; 52: 3439 - 3445. 


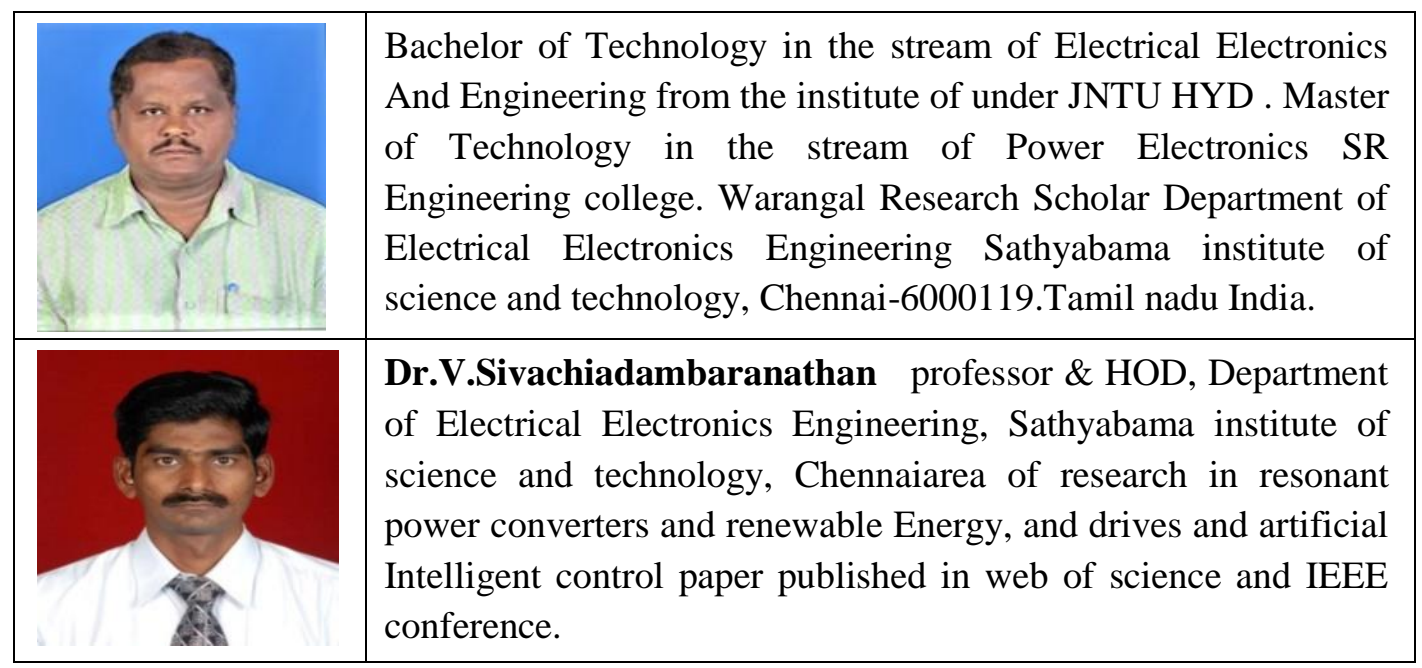

